\title{
ANTIOXIDATIVE EFFECTS OF $N$-ACETYLCYSTEINE, LIPOIC ACID, TAURINE, AND CURCUMIN IN THE MUSCLE OF CYPRINUS CARPIO L. EXPOSED TO CADMIUM
}

\author{
Yusuf SEVGILER ${ }^{1}$, Sahire KARAYTUG ${ }^{2}$, and Fahri KARAYAKAR ${ }^{2}$ \\ Adiyaman University, Faculty of Science and Letters, Department of Biology, Adiyaman ${ }^{1}$, \\ University of Mersin, Faculty of Aquaculture, Yenişehir Campus, Mersin'2, Turkey \\ Received in October 2010 \\ CrossChecked in October 2010 \\ Accepted in February 2011
}

\begin{abstract}
We investigated the muscle tissue of a teleost Cyprinus carpio L. to find out whether $N$-acetylcysteine (NAC), alpha-lipoic acid (LA), taurine (TAU), and curcumin (CUR) were able to counteract oxidative stress induced by acute exposure to cadmium $(\mathrm{Cd})$. The muscle tissue was dissected $96 \mathrm{~h}$ after a single intraperitoneal injection of $\mathrm{Cd}\left(5 \mathrm{mg} \mathrm{kg}^{-1}\right)$ and of antioxidant substances $\left(50 \mathrm{mg} \mathrm{kg}^{-1}\right)$. Using spectrophotometry, we determined the glutathione redox status, lipid peroxidation levels and the activities of superoxide dismutase (SOD), catalase (CAT), glutathione peroxidase (GPx), and glutathione disulphide reductase (GR). Accumulation of $\mathrm{Cd}$ in the muscle was analysed using inductively coupled plasma - optical emission spectrometry (ICP-OES).

All substances lowered Cd levels in the following order of efficiency; LA=NAC $>$ TAU $=C U R$. Cadmium increased SOD activity, but CAT activity declined, regardless of antioxidant treatment. Treatment with CUR induced GPx activity. Treatment with TAU lowered Cd due to higher total glutathione (tGSH). The most effective substances on lipid peroxidation were LA and NAC due to a greater Cd-lowering potential. It seems that the protective role of TAU, LA, and NAC is not necessarily associated with antioxidant enzymes, but rather with their own activity.
\end{abstract}

KEY WORDS: accumulation, antioxidants, fish, muscle, oxidative stress

Studies of the protective role of exogenous antioxidants against $\mathrm{Cd}$ toxicity in living organisms have mostly been limited to mammals and have seldom included aquatic organisms. Yet, aquatic organisms are more sensitive to $\mathrm{Cd}$ exposure and toxicity than mammals and may provide a good experimental model for the evaluation of subtle effects of oxidative stress and other adverse effects of pollutants (1). Fish are often not directly exposed to $\mathrm{Cd}$, because they are often at the top of aquatic food chains (2).

Cadmium is a heavy metal; about $18,800 \mathrm{t}$ were produced worldwide for nickel-Cd batteries, pigments, chemical stabilizers, metal coatings and alloys in 2009 alone (3). The oxidative potential of $\mathrm{Cd}$ in animals is well-known; it depletes glutathione (GSH) and induces or inhibits antioxidant enzymes and lipid peroxidation (4-6).

A useful protection against its oxidative effects could be supplementation with antioxidants. $\mathrm{N}$ acetylcysteine (IUPAC name: $(R)$-2-acetamido-3sulfanylpropanoic acid; CAS number: 696-91-1; NAC) has widely been used to protect against the toxic effects of a number of chemicals. It is a free-radical scavenger, a precursor of GSH, and it can form stable 
water-soluble complexes with mercury and other metals (7).

Alpha-lipoic acid (thioctic acid; IUPAC name: (R)-5-(1,2-dithiolan-3-yl) pentanoic acid; CAS number: 1200-22-2; LA) is a disulphide compound and a natural coenzyme of pyruvate dehydrogenase and $\alpha$-ketoglutarate dehydrogenase. Lipoic acid and its reduced form dihydrolipoic acid are present in all kinds of microbial and eukaryotic cells and act as antioxidants not only through free-radical quenching, but also indirectly through recycling other cellular antioxidants (8). Its potential as a chelating agent against heavy metal poisoning was also evaluated by some laboratories $(9,10)$.

Taurine (IUPAC name: 2-aminoethanesulfonic acid; CAS number: 107-35-7; TAU), a semi-essential amino acid, is known to have antioxidant, membranestabilising properties, as it inhibits lipid peroxides (11). Contradictory data were reported for the kidney of a teleost Clarias batrachus and mice treated with TAU. It lowered $\mathrm{Cd}$ content in the fish and mice, but lipid peroxidation decreased only in mice $(12,13)$.

Curcumin [diferuoyl methane, IUPAC name: (1E,6E)-1,7-bis (4-hydroxy-3-methoxyphenyl)-1,6heptadiene-3,5-dione; CAS number: 458-37-7; CUR] from the rhizomes of turmeric (Curcuma longa $\mathrm{L}$.) is a phenolic and natural yellow pigment. Its biological activity has been studied by many. Daniel et al. (14) reported that CUR chelated $\mathrm{Cd}$ and lead in solutions and decreased lipid peroxidation induced by these metals in rat brain homogenate. Curcumin possesses antioxidative and anti-inflammatory properties, and Eybl et al. $(15,16)$ associated it with a drop in $\mathrm{Cd}$ content in vivo in rats and mice.

The muscle tissue was chosen in this study because of its usage as food supply by humans as well as high levels of oxygen consumption which results in higher concentrations of ROS compared to other tissues (17). The goal of the present study was to investigate the effect of antioxidant compounds NAC, LA, CUR and TAU on oxidative damage induced by $\mathrm{Cd}$ by whether their antioxidant and/or Cd-decreasing potential in the muscle of carp (Cyprinus carpio L.) used as a model organism.

\section{MATERIALS AND METHODS}

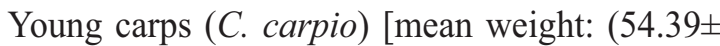
$3.11) \mathrm{g}$; mean length: $(16.02 \pm 0.47) \mathrm{cm}]$ were obtained from the State Hydraulic Works fish culture pools (Adana, Turkey) and transferred to our laboratory. The animals were placed in glass tanks for a month before the experiments to get acclimatised to laboratory conditions. The experimental tanks were filled with $120 \mathrm{~L}$ of dechlorinated and gently aerated tap water with the following physicochemical properties: total hardness (318.60 44.74$) \mathrm{mg} \mathrm{L}^{-1} \mathrm{CaCO}_{3} ; \mathrm{pH}(8.65 \pm 0.04)$, dissolved oxygen (7.49 \pm 0.09$) \mathrm{mg} \mathrm{L}^{-1}$ and temperature $(22.6 \pm 0.6){ }^{\circ} \mathrm{C}$. Light and dark cycles exchanged every $12 \mathrm{~h}$. The fish were fed with commercial food pellets (Camli Feed Co., Izmir, Turkey) once a day, receiving about $2 \%$ of their body weight per meal.

The experiments followed the American Public Health Association (APHA) standard methods (18). The fish were divided into seven experimental tanks; each tank accommodating four fish. All experimental chemicals were given in a single intraperitoneal (i.p.) dose injected after anaesthetising the fish with icecontaining water because of the interference of chemical anaesthetics with GSH metabolism (19). All experimental doses were determined with preexperimental results according to the effects of chemicals on lipid peroxidation.

Curcumin was dissolved in ethyl oleate (14), while $\mathrm{CdCl}_{2}, \mathrm{NAC}, \mathrm{LA}$, and TAU were dissolved in saline $(0.59 \% \mathrm{NaCl}$ for freshwater fish). Antioxidants NAC, LA, TAU, and CUR were injected immediately after $\mathrm{Cd}$. The fish then were returned into experimental tanks for $96 \mathrm{~h}$ and experimental water was not changed during experiments.

\section{Experimental design}

Fish in the control group received $150 \mu \mathrm{L}$ of saline. Oleate control fish received $150 \mu \mathrm{L}$ of ethyl oleate. Fish in the $\mathrm{Cd}$ group received $5 \mathrm{mg} \mathrm{kg}^{-1} \mathrm{Cd}$ alone. Fish in the $\mathrm{Cd}+\mathrm{NAC}$ group received $50 \mathrm{mg} \mathrm{kg}^{-1} \mathrm{NAC}$ immediately after receiving $5 \mathrm{mg} \mathrm{kg}^{-1} \mathrm{Cd}$. Fish in the $\mathrm{Cd}+\mathrm{LA}$ group received $50 \mathrm{mg} \mathrm{kg}^{-1} \mathrm{LA}$ immediately after receiving $5 \mathrm{mg} \mathrm{kg}^{-1} \mathrm{Cd}$. Fish in the $\mathrm{Cd}+\mathrm{TAU}$ group received $50 \mathrm{mg} \mathrm{kg}^{-1}$ TAU immediately after receiving $5 \mathrm{mg} \mathrm{kg}^{-1} \mathrm{Cd}$. The last $\mathrm{Cd}+\mathrm{CUR}$ group of fish received $50 \mathrm{mg} \mathrm{kg}^{-1}$ CUR immediately after receiving $5 \mathrm{mg} \mathrm{kg}^{-1} \mathrm{Cd}$.

No fish died during the experiments. Ninety-six hours after injection the fish were removed from the tanks and killed by decapitation. Their muscle tissue was dissected out on an ice-cold plate, washed with saline, blotted dry, weighed, and stored at $-80{ }^{\circ} \mathrm{C}$ until analysis. 
A part of muscle tissue from each fish was washed with saline and analysed for $\mathrm{Cd}$ using the method of Muramoto (20). Oven-dried muscle samples were digested in a mixture of nitric and perchloric acid (2:1). Cadmium was analysed with a Perkin-Elmer 5300 DV ICP-OES spectrometer (USA). The instrument was calibrated and the standard curve prepared using custom standards supplied by Inorganic Ventures Inc. (USA), with a detection limit of $0.02 \mathrm{mg} \mathrm{L}^{-1}$.

Muscle tissues were homogenised in a teflon homogeniser (Daihan, WiseStir, HS30E, Korea) with $0.25 \mathrm{~mol} \mathrm{~L}^{-1}$ sucrose (Fluka, Switzerland) containing a $50 \mathrm{mmol} \mathrm{L}^{-1}, \mathrm{pH} 7.4$ phosphate buffer. Homogenates were centrifuged at $9500 \mathrm{x} g$ (Hettich Universal 320R, Germany). The whole homogenisation process was carried out at $4{ }^{\circ} \mathrm{C}$. Supernatants were used to determine tGSH, oxidised glutathione (GSSG), thiobarbituric acid reactive substances (TBARS), protein content, and SOD, CAT, GPx, and GR activities.

The activity of SOD was measured using the method described by McCord and Fridovich (21). The inhibition of iodo- $p$-nitro tetrazolium violet reduction by superoxide anion radical $\left(\mathrm{O}_{2}^{-}\right)$generated by xanthine-xanthine oxidase was monitored at $505 \mathrm{~nm}$ (Shimadzu UV-Mini 1208, Japan) for $3 \mathrm{~min}$ at $37^{\circ} \mathrm{C}$. A standard graphic formed by RANSOD kit (Randox Laboratories Ltd., UK) was used to evaluate enzyme activity.

Catalase activity was determined according to Beutler (22) as decrease in absorbance of $10 \mathrm{mmol}$ $\mathrm{L}^{-1} \mathrm{H}_{2} \mathrm{O}_{2}$ at $37{ }^{\circ} \mathrm{C}$ for $2.5 \mathrm{~min}$. $\left(\varepsilon=0.71 \mathrm{~L} \mathrm{~mol}^{-1} \mathrm{~cm}^{-1}\right)$ in Tris- $\mathrm{HCl}$ buffer ( $\mathrm{pH}$ 8.0). The reaction was initiated by adding $20 \mu \mathrm{L}$ of the sample. The rate of degradation of $\mathrm{H}_{2} \mathrm{O}_{2}$ by CAT was measured spectrophotometrically at $230 \mathrm{~nm}$.

Glutathione peroxidase-specific activity was analysed by monitoring the consumption of NADPH by GR at $340 \mathrm{~nm}$ at $37^{\circ} \mathrm{C}$. For substrate we used $t$ butylhydroperoxide (Sigma-Aldrich, USA) (22). The reaction medium contained $0.1 \mathrm{~mol} \mathrm{~L}^{-1} \mathrm{GSH}, 10$ units of GR, $2 \mathrm{mmol} \mathrm{L}^{-1} \mathrm{NADPH}$, and $7 \mathrm{mmol} \mathrm{L}^{-1}$ of $t$ butylhydroperoxide.

Glutathione disulphide reductase-specific activity was assayed by monitoring oxidation of NADPH with GSSG at $37^{\circ} \mathrm{C}$ and at $340 \mathrm{~nm}$ (23). The reaction medium included $100 \mathrm{mmol} \mathrm{L}^{-1}$ phosphate buffer $(\mathrm{pH}$ 8), $0.12 \mathrm{mmol} \mathrm{L}^{-1} \mathrm{NADPH}$, and $1 \mathrm{mmol} \mathrm{L}^{-1} \mathrm{GSSG}$.

Before tGSH and GSSG analysis, homogenates were mixed with $10 \%$ sulphosalicylic acid (SigmaAldrich, USA) at a ratio of 1:0.5 (v:v), further homogenised, and then centrifuged at $9500 \mathrm{x} g$ for 5 min to precipitate the proteins. Total glutathione content in the resulting supernatant was analysed according to Anderson (24). The reaction medium contained $143 \mathrm{mmol} \mathrm{L}^{-1}$ sodium-potassium buffer (containing $6.3 \mathrm{mmol} \mathrm{L}^{-1}$ EDTA, pH 7.5), $0.3 \mathrm{mmol}$ $\mathrm{L}^{-1} \mathrm{NADPH}, 6 \mathrm{mmol} \mathrm{L}-1$ DTNB, and 50 units of GR. The total volume was adjusted to $1 \mathrm{~mL}$ with distilled water. Absorbance was monitored at $412 \mathrm{~nm}$ at $30{ }^{\circ} \mathrm{C}$ and converted to concentration using the standard curve prepared with GSH. Oxidised glutathione content was measured after trapping the reduced fraction with 2-vinylpyridine (25). The derivatised samples were analysed using the same method used for tGSH. Glutathione concentrations were expressed as micromoles of GSH equivalents per miligrame of protein. GSH was calculated by subtracting GSSG levels from $\mathrm{tGSH}$ levels ( $\mathrm{tGSH}=\mathrm{GSH}+2 \mathrm{xGSSG}$ ). The $\mathrm{GSH} / \mathrm{GSSG}$ ratio was calculated using the following formula (26):

$$
\frac{G S H}{G S S G}=\frac{t G S H-G S S G}{G S S G / 2}
$$

Muscle tissue TBARS as a marker of lipid peroxidation was determined according to Ohkawa et al. (27). Homogenates were treated with thiobarbituric acid (TBA) (Sigma-Aldrich, USA) at pH 3.4 and $95^{\circ} \mathrm{C}$ for $30 \mathrm{~min}$, and the absorbance of developing pink colour was measured at $532 \mathrm{~nm}$. The reaction mixture contained $8.1 \%$ of SDS, $20 \%$ of acetic acid, pH 3.4, $0.8 \%$ of TBA, and a mixture of $n$-butanol and pyridine (14:1). The concentration of TBARS was determined using the standard curve prepared with $1,1^{\prime}, 3,3^{\prime}$ tetramethoxypropan.

Protein concentration was measured using a Folinphenol reagent according to Lowry et al. (28). Absorbance was measured at $750 \mathrm{~nm}$ and converted to concentration using bovine serum albumin as a standard.

All parameters were expressed as mean \pm standard error (SE). Equality of variances was tested with Levene's test. Statistical differences between the treated and control groups were determined with the analysis of variance (ANOVA), using SPSS 17.0 statistical package. For homogenous subsets we used Duncan's multiple comparison test and for nonhomogeneous subsets Tamhane's T2 test. The level of significance was set at $5 \%$. Pearson correlation analysis was used to determine whether a decrease in $\mathrm{Cd}$ level was related to other studied parameters. 


\section{RESULTS}

\section{Muscle Cd levels}

Ninety-six hours after treatment we observed a significant accumulation of $\mathrm{Cd}$ in carp muscle (Table 1). All antioxidants lowered its tissue content $(\mathrm{P}<0.05)$ in the following order (from most effective to least): $\mathrm{LA}=\mathrm{NAC}>\mathrm{TAU}=\mathrm{CUR}$. Lipoic acid and NAC lowered the $\mathrm{Cd}$ content by more than $65 \%$, and TAU and CUR by $40 \%$.

\section{Effects of antioxidants on antioxidant enzyme activities}

All tested antioxidants and $\mathrm{Cd}$ alone stimulated SOD activity in the muscle tissue, but the increase was significant only in the $\mathrm{Cd}+\mathrm{LA}$ and $\mathrm{Cd}+\mathrm{CUR}$ groups (Table 2). Cadmium treatment lowered CAT activity by more than $60 \%$. Antioxidants had no effect

Table 1 Carp muscle accumulation of cadmium (Cd) 96 hafter i.p. injection of $5 \mathrm{mg} \mathrm{kg}^{-1} \mathrm{Cd}$ and $50 \mathrm{mg} \mathrm{kg}^{-1}$ of antioxidant

\begin{tabular}{ll}
\hline Groups & $\mathbf{C d} / \boldsymbol{\mu g} \mathbf{g}^{-1} \mathbf{d . w .}$ \\
\hline Control & $<\mathrm{d} .1$. \\
\hline Cd & $0.48 \pm 0.05^{\mathrm{a}}$ \\
\hline Cd+TAU & $0.25 \pm 0.03^{\mathrm{b}}$ \\
\hline Cd+LA & $0.15 \pm 0.03^{\mathrm{b}}$ \\
\hline Cd+CUR & $0.28 \pm 0.03^{\mathrm{b}}$ \\
\hline Cd+NAC & $0.15 \pm 0.03^{\mathrm{b}}$ \\
\hline
\end{tabular}

$N=4$ fish per group

d.w. - dry weight

TAU - taurine, LA - $\alpha$-lipoic acid, CUR - curcumin, NAC

- N-acetylcysteine; given immediately after Cd injection

${ }^{a}$ significantly different from control $(P<0.05)$

${ }^{b}$ significantly different from the Cd group $(P<0.05)$

d.l. $=$ detection limit $\left(0.02 \mathrm{mg} \mathrm{L}^{-1}\right)$ on Cd-lowered CAT activity. Curcumin increased GPx activity by $20 \%$ compared to the oleate control group. Cadmium did not change GR activity.

\section{Effects of antioxidants on GSH redox status}

Neither Cd treatment nor co-treatment with antioxidants affected muscle GSH redox status (Table 3). An exception is TAU, which increased tGSH by more than $60 \%$ compared to fish treated with $\mathrm{Cd}$ alone. This increase was related to TAU lowering the Cd level, $\mathrm{r}^{2}=-0.708, P<0.05$ (Figure 1).

\section{Effects of antioxidants on lipid peroxidation}

Treatment with Cd alone increased TBARS content in carp muscle, but not significantly (Table 4). Lipid peroxidation dropped $60 \%$ with LA and NAC compared to the $\mathrm{Cd}$ group and correlated with a decrease in $\mathrm{Cd}$ accumulation caused by LA and NAC co-treatments $\left(\mathrm{r}^{2}=0.840, \mathrm{P}<0.01\right.$ and $\mathrm{r}^{2}=0.762, \mathrm{P}<0.05$, respectively) (Figure 2). No antioxidative effect was observed in the Cd+CUR group, while other compounds were effective in the following order: $\mathrm{LA}=\mathrm{NAC}>\mathrm{TAU}$.

Neither Cd nor any of the antioxidants significantly changed tissue protein content (Table 4).

\section{DISCUSSION}

This study has shown that co-treatment with antioxidants, LA and NAC in particular, plays an important role in preventing $\mathrm{Cd}^{2+}$ accumulation and its oxidative effects in carp muscle tissue. Lipoic acid

Table 2 Carp muscle antioxidant enzyme activities $96 \mathrm{~h}$ after i.p. injection of $5 \mathrm{mg} \mathrm{kg}^{-1} \mathrm{Cd}$ and $50 \mathrm{mg} \mathrm{kg}^{-1}$ of antioxidant

\begin{tabular}{lcccc}
\hline Groups & SOD & ENZYME ACTIVITIES / U mg-1 protein & GR \\
\hline Control & $2.51 \pm 0.57$ & $90.22 \pm 16.09$ & $0.78 \pm 0.07$ & $0.029 \pm 0.004$ \\
\hline Oleate control & $3.56 \pm 0.48$ & $80.87 \pm 11.45$ & $0.76 \pm 0.02$ & $0.020 \pm 0.001$ \\
\hline Cd & $8.01 \pm 1.07$ & $27.73 \pm 3.54^{\mathrm{a}}$ & $0.80 \pm 0.03$ & $0.030 \pm 0.004$ \\
\hline Cd+TAU & $10.02 \pm 1.60$ & $45.67 \pm 5.01^{\mathrm{a}}$ & $0.75 \pm 0.02$ & $0.028 \pm 0.004$ \\
\hline Cd+LA & $9.89 \pm 0.61^{\mathrm{a}}$ & $48.70 \pm 7.86^{\mathrm{a}}$ & $0.76 \pm 0.02$ & $0.036 \pm 0.003$ \\
\hline Cd+CUR & $11.73 \pm 0.42^{\mathrm{a}}$ & $30.96 \pm 9.01^{\mathrm{a}}$ & $0.90 \pm 0.01^{\mathrm{a}}$ & $0.035 \pm 0.004$ \\
\hline Cd+NAC & $10.58 \pm 2.71$ & $24.95 \pm 1.73^{\mathrm{a}}$ & $0.57 \pm 0.07$ & $0.027 \pm 0.001$ \\
\hline
\end{tabular}

$N=4$ fish per group

$S O D$ - superoxide dismutase, CAT-catalase, GPX-glutathione peroxidase, GR - glutathione disulfide reductase TAU - taurine, LA - $\alpha$-lipoic acid, CUR - curcumin, NAC - N-acetylcysteine; given immediately after Cd injection a significantly different from corresponding control group (the control for $C d+C U R$ was the oleate group) $(P<0.05)$ 
Table 3 Carp muscle GSH redox status 96 h after i.p. injection of $5 \mathrm{mg} \mathrm{kg}^{-1} \mathrm{Cd}$ and $50 \mathrm{mg} \mathrm{kg}^{-1}$ of antioxidant

\begin{tabular}{lcccc}
\hline \multicolumn{5}{c}{ Glutathione $/ \boldsymbol{\mu}$ mol $\mathbf{~ g}^{-1}$ protein } \\
\hline Groups & tGSH & GSH & GSSG & GSH/GSSG \\
\hline Control & $11.74 \pm 1.40$ & $8.90 \pm 1.01$ & $1.61 \pm 0.09$ & $11.66 \pm 0.62$ \\
\hline Oleate control & $8.96 \pm 1.30$ & $7.51 \pm 1.11$ & $1.86 \pm 0.05$ & $10.33 \pm 0.37$ \\
\hline Cd & $8.56 \pm 0.68$ & $7.25 \pm 0.65$ & $1.27 \pm 0.02$ & $11.82 \pm 0.72$ \\
\hline Cd+TAU & $14.34 \pm 1.50^{\mathrm{b}}$ & $8.19 \pm 1.18$ & $2.27 \pm 0.15$ & $11.00 \pm 0.30$ \\
\hline Cd+LA & $8.03 \pm 1.11$ & $6.78 \pm 1.04$ & $1.38 \pm 0.09$ & $12.70 \pm 0.37$ \\
\hline Cd+CUR & $8.15 \pm 1.52$ & $6.71 \pm 1.37$ & $2.15 \pm 0.25$ & $11.36 \pm 0.38$ \\
\hline Cd+NAC & $9.61 \pm 0.88$ & $7.15 \pm 0.86$ & $1.01 \pm 0.09$ & $11.13 \pm 0.95$ \\
\hline
\end{tabular}

$N=4$ fish per group

GSH - glutathione; $t G S H$ - total glutathione, GSSG - oxidised glutathione

TAU - taurine, LA - $\alpha$-lipoic acid, CUR - curcumin, NAC - N-acetylcysteine; given immediately after Cd injection

significantly different from the $C d$ group $(P<0.05)$

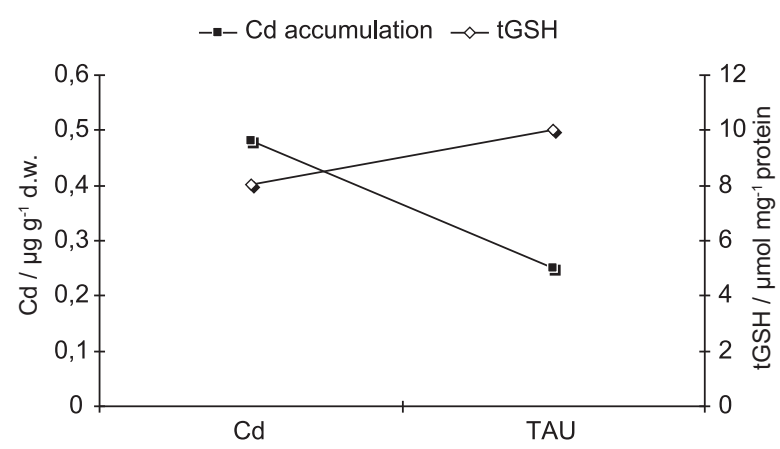

Figure 1 Relationship between cadmium (Cd) accumulation and total glutathione (tGSH) content in the muscle of carp treated with $C d+T A U$.

TAU - taurine; given i.p. $\left(50 \mathrm{mg} \mathrm{kg}^{-1}\right)$ immediately after Cd injection

d.w. - dry weight

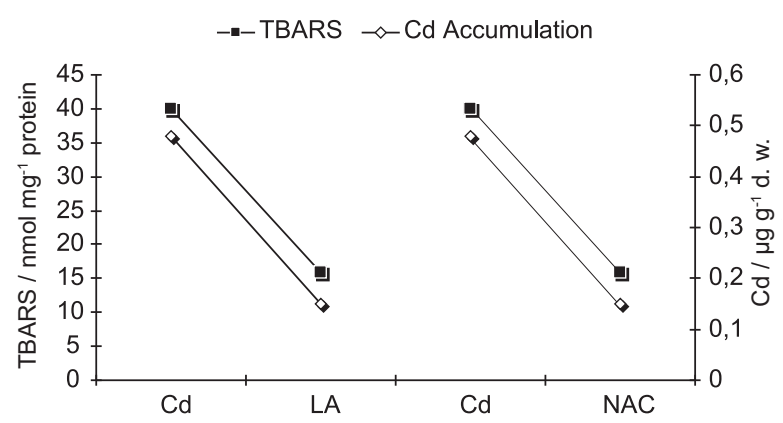

Figure 2 Relationship between cadmium (Cd) accumulation and lipid peroxidation levels in carp treated with $C d+L A$ and $C d+N A C$, respectively

TBARS - thiobarbituric acid reactive substances $L A-\alpha$-lipoic acid, $N A C-N$-acetylcysteine were given i.p. $\left(50 \mathrm{mg} \mathrm{kg}^{-1}\right)$ immediately after Cd injection

was more effective than TAU and CUR. It is a potent chelator, especially of divalent redox-active metal ions such as $\mathrm{Cu}^{2+}, \mathrm{Zn}^{2+}$, and $\mathrm{Pb}^{2+}(29)$. In contrast, an acute toxicity study (30) showed that LA injected with $\mathrm{Cd}$
Table 4 Carp muscle TBARS and protein content $96 \mathrm{~h}$ after i.p. injection of $5 \mathrm{mg} \mathrm{kg}^{-1} \mathrm{Cd}$ and $50 \mathrm{mg} \mathrm{kg}^{-1}$ of antioxidant

\begin{tabular}{lcc}
\hline Groups & $\begin{array}{c}\text { TBARS / } \\
\text { nmol } \text { mg }^{-1} \\
\text { protein }\end{array}$ & $\begin{array}{c}\text { Protein / } \\
\text { mg mL }^{-1} \\
\text { homogenate }\end{array}$ \\
\hline Control & $25.50 \pm 2.50$ & $0.19 \pm 0.01$ \\
\hline Oleate control & $23.30 \pm 2.21$ & $0.17 \pm 0.01$ \\
\hline Cd & $39.89 \pm 10.55$ & $0.19 \pm 0.02$ \\
\hline Cd+TAU & $28.98 \pm 3.30$ & $0.17 \pm 0.03$ \\
\hline Cd+LA & $15.82 \pm 1.50^{\mathbf{b}}$ & $0.24 \pm 0.02$ \\
\hline Cd+CUR & $40.40 \pm 7.95$ & $0.19 \pm 0.03$ \\
\hline Cd+NAC & $15.85 \pm 4.03^{\mathbf{b}}$ & $0.24 \pm 0.02$ \\
\hline
\end{tabular}

$N=4$ specimens per group

TBARS - thiobarbituric acid reactive substances

TAU - taurine, LA - $\alpha$-lipoic acid, CUR - curcumin,

$N A C-\mathrm{N}$-acetylcysteine; given immediately after $C d$ injection

${ }^{\mathbf{b}}$ significantly different from Cd group $(P<0.05)$

had no effect on $\mathrm{Cd}$ accumulation in mice liver, kidney, brain, and testes. In our study, NAC co-injection decreased $\mathrm{Cd}$ content in the muscle, which confirms the findings of Tandon et al. (31) for the liver, kidney and blood tissues of female rats. They have proposed that $\mathrm{Cd}$ detoxification may require a sulphur and an oxygen atom, which LA and NAC can provide. As far as we know, we are the first to report about the detoxifying effects of LA and NAC in a metal-treated teleost, and further in vivo metal-ligand interaction studies with fish species are needed to understand this interaction.

In several acute and sub-acute treatment studies, TAU acted as a Cd detoxifier in the blood, liver, and kidney tissues of mice $(12,32,33)$. It possesses one amino $\left(-\mathrm{NH}_{2}\right)$ and one sulphonate $\left(-\mathrm{SO}_{3} \mathrm{H}\right)$ group, which may be responsible for its detoxifying action. 
Similar to our findings, TAU exhibited lowered subchronic $\mathrm{Cd}$ accumulation in the liver and kidney of Clarias batrachus (13).

Curcumin owes its chelating property to the $\beta$ diketone moiety $(34,35)$. Infra-red spectral analysis has shown that CUR with its hydroxyl groups and $\beta$-diketone moiety binds directly or indirectly to toxic metals, including $\mathrm{Cd}$, through strong metal-ligand interactions (14). In contrast to our results, however, acute CUR pre-treatment by gastric gavage had no effect on acute $\mathrm{Cd}$ accumulation in the liver, kidney, brain, and testes of mice and rats $(15,16)$. We too found that liver $\mathrm{Cd}$ was not affected by CUR cotreatment in carp $96 \mathrm{~h}$ after i.p. injection (unpublished data). We are the first to report about decreasing efficiency of CUR co-treatment in muscle tissue of a teleost and we thought that this effect may be owed to tissue-specific action.

Superoxide dismutase, CAT, and GPx enzymes provide first-line cell defence against toxic ROS action. In our study, SOD activity in carp muscle revealed higher $\mathrm{Cd}$-induced $\mathrm{O}_{2}^{-}$production. According to Kono and Fridovich (36) excessive $\mathrm{O}_{2}^{-}$accumulation inhibits CAT activity and SOD prevents this inhibition but does not reverse it in vitro. They reported that this synergism may be important in vivo, but we could not confirm it. In another study, sub-chronic $\mathrm{Cd}$ treatment induced SOD and decreased CAT activity in rat kidney and the authors have suggested that $\mathrm{Cd}$ can reduce enzyme activities which have a $\mathrm{Fe}$ ion in their active sites such as CAT by decreasing liver and kidney Fe levels (37). In a study by Kumar et al. (13) Cd exposure increased SOD and CAT activity in the liver and kidney of C. batrachus, while TAU had no effect on SOD activity. Bludovská et al. (30) reported that LA altered Cd-induced CAT inhibition in the liver of mice. In contrast, CUR did not affect liver CAT activity lowered by $\mathrm{Cd}$ treatment in mice (16), but improved SOD and CAT activities in the liver of sodium arseniteexposed rats in another study by El-Demerdash et al. (38). The authors concluded that the protective role of antioxidants against $\mathrm{Cd}$-induced oxidative stress is not necessarily associated with antioxidant enzyme activities.

Eybl et al. (39) found that neither $\mathrm{Cd}$ nor $\mathrm{Cd}+\mathrm{CUR}$ treatments affected liver GPx activity in mice. In our study, CUR may have caused $\mathrm{H}_{2} \mathrm{O}_{2}$ accumulation in carp muscle, reflected by higher SOD and lower CAT activity, which in turn may have increased GPx activity. In another study (40), curcumin caused a sudden rise in ROS levels in mice L929 fibroblast cells, and this effect was blocked by antioxidants NAC and GSH. Induced GPx activity could also be related to higher lipid peroxide levels in $\mathrm{Cd}+\mathrm{CUR}$ group. A more detailed investigation should be able to answer if $\mathrm{ROS}$ accumulation in $\mathrm{Cd}$-exposed teleost species is related to CUR.

Thiol-based intracellular antioxidant system is considered to be the second line of cellular defence against ROS-mediated oxidative damage (33). It is well-known that cellular GSH redox status is affected by $\mathrm{Cd}$ action $(41,42)$. This, however, is questioned by the results of our and other studies in which $\mathrm{Cd}$ had no effect on cellular GSH redox status $(43,44)$. Thijssen et al. (44) reported that the treatment of mice

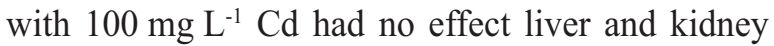
GSH and GSSG levels, and that cellular redox status was protected by elevated metallothionein levels, which are important in $\mathrm{Cd}$ detoxification. Nonenzymatic reaction between $\mathrm{GSH}$ and $\mathrm{O}_{2}^{-}$radical is well-known (45). The rise in tGSH levels in the TAU co-treated group in our study may also be an adaptive response to $\mathrm{O}_{2}^{-}$elevation, reflected by SOD activity. As there was no change in GSH and GSSG level, we believe that SOD activity is more important in protecting the cell against $\mathrm{Cd}$-induced ROS effect than GSH.

In our study, GR did not vary significantly across groups, most probably because it is usually activated by a disturbance in the GSH/GSSG ratio (which reflects cellular thiol redox status), and this ratio was not disturbed.

Kumar et al. (13) have reported that Cd catalyses oxidation of biomolecules and that its destructive effects on cell components could be weakened by antioxidants. While studies disagree whether exogenous antioxidants can lower lipid peroxidation and $\mathrm{Cd}$ levels at the same time, the action of LA and $\mathrm{NAC}$, as the most effective antioxidants in our study, was related to lowering $\mathrm{Cd}$ levels, and not as much to stimulating antioxidant enzyme activity. Müller and Menzel (9) reported that LA complexes with intra- and extracellular $\mathrm{Cd}$ in isolated rat hepatocytes protected rat liver cells from $\mathrm{Cd}$-induced membrane destruction. While in the study by Buldovská et al. (30) LA did lower $\mathrm{Cd}$-induced lipid peroxidation to control levels in mice liver, it did not change tissue $\mathrm{Cd}$ content. Neither did NAC, in the study by Jones et al. (45), change tissue $\mathrm{Cd}$ contents or improve enzymatic and non-enzymatic antioxidant levels in the kidney of $\mathrm{Cd}$-treated rats; it decreased renal $\mathrm{Cd}$ toxicity by 
decreasing Cd-induced lipid peroxidation (46). In our study and the study by Kumar et al. (13), TAU lowered both lipid peroxidation and $\mathrm{Cd}$ tissue content. Curcumin, however, was not effective against lipid peroxidation; its pro-oxidant properties have also been confirmed by Thayyullathil et al. (40).

\section{CONCLUSION}

To sum up, the antioxidants used in this study seem not only to counter the oxidative effects of $\mathrm{Cd}$, but also to reduce its tissue content. The most efficient against $\mathrm{Cd}$ toxicity are LA and NAC, followed by TAU, and CUR. We have also observed that their protective role is not necessarily associated with antioxidant enzymes, but rather to their own activity.

\section{Acknowledgement}

Adiyaman University Scientific Research Commission is gratefully acknowledged for supporting the project FEFBAP2008-5. We declare no conflict of interest whatsoever.

\section{REFERENCES}

1. Lackner R. "Oxidative stress" in fish by environmental pollutants. In: Braunbeck T, Hinton DE, Streit B, editors. Fish Ecotoxicology. Basel: Birkhauser Verlag; 1998. p. 203-24.

2. Lushchak VI. Oxidative stress as a component of transition metal toxicity in fish. In: Svensson EP, editor. Aquatic Toxicology Research Focus. Hauppauge (NY): Nova Science Publishers Inc.; 2008. p. 1-29.

3. Tolcin AC. Cadmium. In: U.S. Geological Survey Mineral Commodity Summaries. Washington: United States Government Printing Office; 2010. p. 36-7.

4. Hwang DF, Wang LC. Effect of taurine on toxicity of cadmium in rats. Toxicology 2001;167:173-80.

5. Basha PS, Rani AU. Cadmium-induced antioxidant defense mechanism in freshwater teleost Oreochromis mossambicus (Tilapia). Ecotox Environ Saf 2003;56:218-21.

6. Soares SS, Martins H, Gutiérrez-Merino C, Aureliano M. Vanadium and cadmium in vivo effects in teleost cardiac muscle: metal accumulation and oxidative stress markers. Comp Biochem Physiol C 2008;147:168-78.

7. Goyer RA, Clarkson TW. Toxic effects of metals. In: Klaassen CD, editor. Casarett and Doull's Toxicology: The Basic Science of Poisons. $6^{\text {th }}$ ed. New York (NY): McGraw-Hill; 2001. p. 811-67.

8. Aly HAA, Lightfoot DA, El-Shemy HA. Modulatory role of lipoic acid on lipopolysaccharide-induced oxidative stress in adult rat Sertoli cells in vitro. Chem Biol Interact 2009;182: 112-8.

9. Müller L, Menzel H. Studies on the efficacy of lipoate and dihydrolipoate in the alteration of cadmium ${ }^{2+}$ toxicity in isolated hepatocytes. Biochim Biophys Acta 1990;1052: 386-91.

10. Lodge JK, Traber MG, Packer L. Thiol chelation of $\mathrm{Cu}^{2+}$ by dihydrolipoic acid prevents human low density lipoprotein peroxidation. Free Radic Biol Med 1998;25:287-97.

11. Patrick L. Lead toxicity part II: the role of free radical damage and the use of antioxidants in the pathology and treatment of lead toxicity. Altern Med Rev 2006;11:114-27.

12. Manna P, Sinha M, Sil PC. Taurine plays a beneficial role against cadmium-induced oxidative renal dysfunction. Amino Acids 2009;36:417-28.

13. Kumar P, Prasad Y, Patra AK, Ranjan R, Swarup D, Patra $\mathrm{RC}, \mathrm{Pal} \mathrm{S}$. Ascorbic acid, garlic extract and taurine alleviate cadmium-induced oxidative stress in freshwater catfish (Clarias batrachus). Sci Total Environ 2009;407:5024-30.

14. Daniel S, Limson JL, Dairam A, Watkins GM, Daya S. Through metal binding, curcumin protects against lead- and cadmium-induced lipid peroxidation in rat brain homogenates and against lead-induced tissue damage in rat brain. J Inorg Biochem 2004;98:266-75.

15. Eybl V, Kotyzová D, Bludovská M. The effect of curcumin on cadmium-induced oxidative damage and trace elements level in the liver of rats and mice. Toxicol Lett 2004;151: 79-85.

16. Eybl V, Kotyzová D, Lesetický L, Bludovská M, Koutensky $\mathrm{J}$. The influence of curcumin and manganese complex of curcumin on cadmium-induced oxidative damage and trace elements status in tissues of mice. J Appl Toxicol 2006;26: 207-12.

17. Fulle S, Protasi F, Di Tano G, Pietrangelo T, Beltramin A, Boncompagni S, Vecchiet L, Fano G. The contribution of reactive oxygen species to sarcopenia and muscle ageing. Exp Gerontol 2004;39:17-24.

18. Clescerl LS, Greenberg AE, Eaton AD, editors. Standard Methods for the Examination of Water and Wastewater. $20^{\text {th }}$ ed. Washington (DC): American Public Health Association; 1999.

19. Peña-Llopis $\mathrm{S}$, Ferrando MD, Peña JB. Fish tolerance to organophosphate-induced oxidative stress is dependent on the glutathione metabolism and enhanced by $N$-acetylcysteine. Aquat Toxicol 2003;65:337-60.

20. Muramoto S. Elimination of copper from $\mathrm{Cu}$-contaminated fish by long term exposure to EDTA and freshwater. J Environ Sci Health A 1983;18:455-61.

21. McCord JM, Fridovich I. Superoxide dismutase: An enzymatic function for erythrocuprein (hemocuprein). J Biol Chem 1969;244:6049-55.

22. Beutler E. Red Cell Metabolism: A Manual of Biochemical Methods. New York (NY): Grune and Starton; 1984.

23. Carlberg I, Mannervik B. Purification and characterization of the flavoenzyme glutathione reductase from rat liver. J Biol Chem 1975;250:5475-80.

24. Anderson ME. Determination of glutathione and glutathione disulfide in biological samples. Methods Enzymol 1985;113:548-55

25. Griffith OW. Determination of glutathione and glutathione disulfide using glutathione reductase and 2-vinylpyridine. Anal Biochem 1980;106:207-12. 
26. Peña-Llopis S, Peña JB, Sancho E, Fernández-Vega C, Ferrando MD. Glutathione-dependent resistance of the European eel Anguilla anguilla to the herbicide molinate. Chemosphere 2001;45:671-81.

27. Ohkawa H, Ohishi N, Tagi K. Assay for lipid peroxides in animal tissues by thiobarbituric acid reaction. Anal Chem 1979;95:351-8

28. Lowry OH, Rosebrough NJ, Farr AL, Randall RJ. Protein measurement with folin phenol reagent. J Biol Chem 1951;193:265-75.

29. Shay KP, Moreau RF, Smith EJ, Smith AR, Hagen TM. Alpha-lipoic acid as a dietary supplement: Molecular mechanisms and therapeutic potential. Biochim Biophys Acta 2009;1790:1149-60.

30. Bludovská M, Kotyzová D, Koutensky J, Eybl V. The influence of alpha-lipoic acid on the toxicity of cadmium. Gen Physiol Biophys 1999;18:28-32.

31. Tandon SK, Prasad S, Singh S. Chelation in metal intoxication: influence of cysteine or $N$-Acetyl cysteine on the efficacy of 2,3-dimercaptopropane-1-sulphonate in the treatment of cadmium toxicity. J Appl Toxicol 2002;22: 67-71.

32. Sinha M, Manna P, Sil PC. Cadmium-induced neurological disorders: prophylactic role of taurine. J Appl Toxicol 2008;28:974-86.

33. Sinha M, Manna P, Sil PC. Induction of necrosis in cadmiuminduced hepatic oxidative stress and its prevention by the prophylactic properties of taurine. J Trace Elem Med Biol 2009;23:300-13.

34. Schwarz K, Mertz W. A physiological role of chromium (III) in glucose utilization (glucose tolerance factor). Fed Proc 1961;20:111-4.

35. Albert A. Design of chelating agents for selected biological activity. Fed Proc 1961;20:137-47.

36. Kono Y, Fridovich I. Superoxide radicals inhibit catalase. J Biol Chem 1982;257:5751-4.

37. Jurczuk M, Brzóska MM, Moniuszko-Jakoniuk J, GałazynSidorczuk M, Kulikowska-Karpińska E. Antioxidant enzymes activity and lipid peroxidation in liver and kidney of rats exposed to cadmium and ethanol. Food Chem Toxicol 2004;42:429-38.

38. El-Demerdash FM, Yousef MI, Radwan FME. Ameliorating effect of curcumin on sodium arsenite-induced oxidative damage and lipid peroxidation in different rat organs Food Chem Toxicol 2009;47:249-54.

39. Eybl V, Kotyzova D, Koutensky J. Comparative study of natural antioxidants - curcumin, resveratrol and melatonin - in cadmium-induced oxidative damage in mice. Toxicology 2006;225:150-6.

40. Thayyullathil F, Chathoth S, Hago A, Patel M, Galadari S. Rapid reactive oxygen species (ROS) generation induced by curcumin leads to caspase-dependent and -independent apoptosis in L929 cells. Free Radic Biol Med 2008;45: 1403-12.

41. Bertin G, Averbeck D. Cadmium: cellular effects, modifications of biomolecules, modulation of DNA repair and genotoxic consequences (a review). Biochimie 2006;88:1549-59.

42. Franco R, Sánchez-Olea R, Reyes-Reyes EM, Panayiotidis MI. Environmental toxicity, oxidative stress and apoptosis: Ménage à Trois. Mutat Res 2009;674:3-22.

43. El-Maraghy SA, Gad MZ, Fahim AT, Hamdy MA. Effect of cadmium and aluminum intake on the antioxidant status and lipid peroxidation in rat tissues. J Biochem Mol Toxicol 2001;15:207-14.

44. Thijssen S, Cuypers A, Maringwa J, Smeets K, Horemans N, Lambrichts I, Van Kerkhove E. Low cadmium exposure triggers a biphasic oxidative stress response in mice kidneys. Toxicology 2007;236:29-41.

45. Jones CM, Lawrence A, Wardman P, Burkitt MJ. Kinetics of superoxide scavenging by glutathione: an evaluation of its role in the removal of mitochondrial superoxide. Biochem Soc Transact 2003;31:1337-9.

46. Wang L, Chen D, Cao J, Liu Z. Protective effect of $N$ acetylcysteine on experimental chronic cadmium nephrotoxicity in immature female rats. Hum Exp Toxicol 2009:28:221-9. 


\section{Sažetak}

\section{ANTIOKSIDATIVNI UČINCI $N$-ACETILCISTEINA, LIPOIČNE KISELINE, TAURINAI KURKUMINA U MIŠIĆNOM TKIVU ŠARANA (CYPRINUS CARPIO L.) TRETIRANIH KADMIJEM}

Cilj istraživanja bio je utvrditi mogu li $N$-acetilcistein (NAC), $\alpha$-lipoična kiselina (LA), taurin (TAU) i kurkumin (CUR) svojim antioksidativnim djelovanjem smanjiti razinu oksidativnog stresa u mišićnom tkivu šarana (Cyprinus carpio L.) akutno otrovanih kadmijem. Uzorci mišićnog tkiva skupljeni su $96 \mathrm{~h}$ nakon što su ribama intraperitonealno injicirani kadmij $\left(5 \mathrm{mg} \mathrm{kg}^{-1}\right) \mathrm{i}$ ispitivani antioksidansi $\left(50 \mathrm{mg} \mathrm{kg}^{-1}\right)$. Primjenom spektrofotometrijskih metoda izmjereni su redoks status glutationa, razine lipidne peroksidacije te aktivnosti enzima superoksid dismutaze (SOD), katalaze (CAT), glutation peroksidaze (GPx) i glutation disulfid reduktaze (GR). Maseni udio kadmija u mišićnom tkivu izmjeren je s pomoću metode induktivno spregnute plazme - optičke emisijske spektrometrije (ICP-OES).

Ispitivani spojevi smanjili su nakupljanje kadmija u tkivu šarana sljedećim redoslijedom: $\mathrm{LA}=\mathrm{NAC}>\mathrm{TAU}=\mathrm{CUR}$. Tretman šarana kadmijem izazvao je porast aktivnosti SOD, ali se aktivnost CAT smanjila bez obzira na primjenu antioksidativnih spojeva. Dodatak CUR pojačao je aktivnost GPx. Dodatak TAU povećao je razinu ukupnoga glutationa te smanjio nakupljanje kadmija. Svi spojevi osim CUR smanjili su razinu lipidne peroksidacije te pretpostavljamo da su LA i NAC pridonijeli detoksifikaciji kadmija. Rezultati istraživanja upućuju na to da testirani spojevi, osim CUR, imaju antioksidativni učinak.

KLJUČNE RIJEČI: akumulacija, antioksidansi, mišićno tkivo, oksidativni stres, riba

\section{CORRESPONDING AUTHOR:}

Yusuf Sevgiler

Adiyaman University

Faculty of Science and Letters

Department of Biology

02040 Adiyaman, Turkey

E-mail:ysevgiler@posta.adiyaman.edu.tr 